\title{
THE RELATIONSHIPS OF SELF CONTROL AND NEUROTICISM PERSONALITY TENDENCY TO UNHEALTHY CREDIT CARD USAGE OF CAREER WOMEN IN SURABAYA
}

\author{
Devi Adilah Sandy \\ Theda Renanita \\ Faculty of Psychology, Ciputra University
}

\begin{abstract}
Everyone can experience stress especially career women. Their work problems can cause stress. Career women go shopping to reduce their stress. Then, credit card become their alternative payment method to pay. However, if the use of credit card is not properly managed, it can lead to unhealthy usage of credit card. This research will explore correlation between three variables there are self-control, neuroticism personality tendencies dan unhealthy usage of credit card. Total participants are 73 career women. Multiply correlation analysis shows self-control and neuroticism personality tendencies are related with unhealthy usage of credit card among career women in Surabaya $(R=0.447 \rho=0.000)$; Partial correlation analysis shows $(1)$ There is no relation between self-control and the unhealthy usage of credit card among career women in Surabaya $(\mathrm{r}=-0.266$ $\rho=0.024)$; (2) There is no relation between neuroticism personality tendencies and the unhealthy usage of credit card among career women in Surabaya $(r=0.321 \rho=0.006)$.
\end{abstract}

Keywords: shopping, copping stress, self-control, neuroticism, unhealthy usage of credit card

Solisting atistics Indonesia reported that the number of job seekers and job fulfillment in East Java for females continue to increase every year. In 2014, the number reached 185.079 million of female job seeker, and the fulfillment of female workforce reached the number 101.922 million. These data increased from the previous year, 2013, with numbers of female job seekers in 2013 reached 103 million, while female workforce fulfillment only reached 44.839 million.

Career women, in their adulthood age, may undergo problems when pursuing their successful career and may begin to feel social tensions. These problems and social tensions do not rule out the possibility to become stressors

\footnotetext{
*Corresponding Author.

e-mail: theda.renanita@ciputra.ac.id
}

for career women. Shopping has become one way to deal with stress (Hama, 2001).

In this modern era, efforts to meet the needs of shopping are getting easier. Data released on the Indonesia Credit Card Association show increased growth and transaction of credit card usage. In January 2015, the credit card growth reached 16 million, and in January 2016 it peaked to 17 million. Credit card transaction also peaked to 21 million in January 2015 , and increased to 22 million transactions in January 2016.

Mitchell and Mickel (1999) describe credit cards as an extension of money whose payments can be deferred. Cohen (2007) adds that credit card serves as a tool for consumers to meet the growing standard of external presentations, since it allows consumers to experience lifestyles beyond their financial capabilities (Phau \& Woo, 2008). 
Devi Adilah Sandy \& Theda Renanita / The Relationships of Self Control and Neuroticism Personality Tendency to Unhealthy Credit Card Usage of Career Women in Surabaya / JEE, Vol. 7, No. 1, March 2018, pp 11-18

Mottola (2012) has conducted research related to women and habit of credit card usage in shopping. The result suggests that women get higher rating in credit card usage than men, indicating that women are very confident about their ability to use credit cards and manage their debt. Most respondents of this study agreed that they could manage their credit card debt and the loans they took. They used credit cards to buy things they cannot afford.

Ingene and Levy (in Yoyok, 2012) state as follows, "There are three reasons why a person chooses to use a credit card than cash. Firstly, consumers need credit or mortgage to buy the desired goods or services. Secondly, consumers want to take advantage of convenience so there is no need to bring cash. Thirdly, consumers are those who are very concerned about the profits gained from buying now and paying later". Increased number of credit card users today also go with many supermarkets or markets that provide a credit card payment system, making purchases easier and more practical.

Besides the benefits gained from using credit card, some habits can lead to unhealthy credit card usage. Khalil (2015) explains that missed or late credit card payment will harm credit card users. Also, excessive transactions will lead to the consumption habit, which is to buy more than their affordable needs. Habit of ignoring financial management can cause another problem. Khalil (2015) adds that credit card users who do not manage their financial aspect properly can lose their sense and are at risk of bankruptcy. Troubling credit card usage can trigger stress to its users.

Hamilton and Khan (in Sumarto, Subroto, \& Arianto, 2011) state two factors that can influence credit card usage, which are excellence and convenience. Safakli (2007) adds that credit card use and ownership motivation can be influenced by convenience, security and comfort. More, Chen (2001) identifies someone's internal and external factors in using a credit card. External factors consist of family environment, peer group, and many more, while internal factors come from someone's own self which are self-control and personality. Therefore, this recent research refers to the internal factors of credit card usage by Chen (2001), which are factors of self-control and personality.

Self control describes an individual's decision through cognitive considerations to determine a behavior that will be exposed later. According Susanti and Nurwidawati (2014), "a person who has low self-control cannot control and lead their behaviors, thus will eventually bring them towards negative and damaging situation to themselves." While someone with high self-control will pay great attention to the behavior appropriate for them to control situations.

In this modern time, it is undeniable that with credit card facility issued by the bank, users are given advantage of the ease and benefits gained from purchases using their credit cards. However, if the transaction is not wellcontrolled, can lead to unhealthy credit card usage behavior. Unhealthy credit card usage includes skipping or late paying credit card bills, and triggers consumption habits or spending more than they need. Individuals with low self-control have a greater risk to experience negative impact (Kurniawan \& Suparna, 2014). Individuals with low self-control do not take careful considerations when purchasing something especially using credit card, while someone with high self-control make consideration in buying something especially using credit 
Devi Adilah Sandy \& Theda Renanita / The Relationships of Self Control and Neuroticism Personality Tendency to Unhealthy Credit Card Usage of Career Women in Surabaya / JEE, Vol. 7, No. 1, March 2018, pp 11-18

card. Besides self-control, personality is also assumed to have an effect on someone making purchases using a credit card (Chen, 2001).

McCrae and Costa (in Feist \& Feist, 2010) reveal about "the five traits in personality widely known as the Big Five Theory of Neuroticism, Extraversion, Openness, Agreeableness, and Consciousness. Neuroticism is an individual's tendency to become someone with anxious temperament, self-conscious, selfpity, emotional, and vulnerable to stress disorders. Extraversion is cheerful, tend to pay attention to others, talkative, love to be with others, and a fun-seeker. Openness is open to new experiences and tolerant of unfamiliar things. Agreeableness is a tendency to have a soft heart, self-confidence, and generous. Conscientiousness is an individual's tendency to be organized, motivated to achieve goals, diligent and inclined to discipline". In this study, the researchers focus on the influences of personality with a tendency of neuroticism trait towards credit card usage.

Costa and Widiger (in Talamati, 2012) explain that neuroticism refers to the severity of adjustment and the unacceptability of individual emotions. Later, Costa and McCrae (in Feist \& Feist, 2010), individuals with a prominent neuroticism tendency will become anxious and rigid person. "A person with high neuroticism is said to be an anxious, worryness, less able to control emotions, and is often connoted with depression. On the other hand, those with low neuroticism exhibit stable emotions, not temperamental, and are not easily anxious" (Eysenck, in Ramdhani, 2007). Nyhus and Webley (2001) furthermore add that individuals with emotional instability such as having of neuroticism personality tendency are predicted to be more involved with credit card debt and compulsive purchases.
Huang and Lin (2006) suggest that individuals with negative emotional states such as neuroticism have a greater chance to be at risk of making bad purchasing decisions because, as suggested by Pirog and Roberts (2007), shopping and spending money are ways to improve mood of someone with emotional instability.

Credit cards as a convenient payment tool is assumed to become alternative needed by individuals with neuroticism personality tendency that choose to make convenient and easier shopping transactions. The higher the neuroticism personality tendency, the higher the stress-coping level. Thus, if someone does continuous shopping as a way to cope with stress, she or he is definitely at higher risk of being in an unhealthy credit card usage. Based on the above-explained reasons, as well as in relation to overcome unhealthy credit card usage, this research is significant to conduct in order to explore more on the relationships between selfcontrol and neuroticism personality tendency with unhealthy credit card usage of career women.

This research aims to find out the relationships of self-control and neuroticism personality tendency to unhealthy credit card sauge of career women in Surabaya. This research also aims to find out the relationship of self-control to unhealthy credit card usage of career women in Surabaya with neuroticism personality tendency as controlling variable, as well as to find out the relationship of neuroticism personality tendency to unhealthy credit card usage of career women in Surabaya, with self-control as controlling variable.

This research is believed to contribute to the development of psychology as a branch of knowledge, to educate career women about the 
Devi Adilah Sandy \& Theda Renanita / The Relationships of Self Control and Neuroticism Personality Tendency

to Unhealthy Credit Card Usage of Career Women in Surabaya / JEE, Vol. 7, No. 1, March 2018, pp 11-18

risk of unhealthy credit card usage, and as insight, suggestion, and reference to develop credit card policies both for credit card issuers and for the government.

This research is conducted to answer the following hypotheses:

H1: there are relationships of self-control and neuroticism personality tendency to unhealthy credit card usage of career women in Surabaya.

$\mathrm{H} 2$ : there is a relationship of self-control to unhealthy credit card usage of career women in Surabaya.

H3: there is a relationship of neuroticism personality tendency to unhealthy credit card use of career women in Surabaya.

\section{Method}

This research had two independent variables and one dependent variable. The independent variables were self-control and neuroticism personality tendency, while the dependent variable was unhealthy credit card usage. The research subjects were 73 career women with credit cards and have lived in Surabaya. The subjects were chosen by implementing snowball sampling technique since the population size was unknown. Researchers used the snowball sampling technique because the population in this study is unknown. Questionnaires with Likert-scale was used as measuring tool, which was adapted from other related researcher's measuring tool. The researchers used three questionnaires: Self Control Scale, which was adapted from Tangney, Baumeister, and Boone (2004) for self-control scale; Big Five Inventory Scale, adapted from John and Srivastava (1999), for personality tendency scale, and; a scale adapted from Robert and Jones (2001) for measuring unhealthy credit card us- age. All data were analyzed by using multiple correlation analysis, and partial correlation with the help of SPSS version 16.0 for Windows.

\section{Results}

The data normality test was performed using One-Sample Kolmogorov-Smirnov with the help of SPSS 16.0 program. This normality test results showed the value of $\rho=0.878$, indicating that the data were normally distributed ( $\rho \geq 0.05$ ), thus the hypothesis testing was done in parametric way. Hypothesis tests done were multiple correlation and partial correlation.

Table 2 Hypotheses Tests

\begin{tabular}{|c|c|c|}
\hline Hypothesis & Results & Explanation \\
\hline $\begin{array}{l}\text { H1: there are relationships of self- } \\
\text { control and neuroticism } \\
\text { personality tendency to } \\
\text { unhealthy credit card usage of } \\
\text { career women in Surabaya. }\end{array}$ & $\begin{array}{l}\mathrm{R}=0.447 \\
\rho=0.000\end{array}$ & H1 was accepted \\
\hline $\begin{aligned} \mathrm{H} 2: & \text { there is a relationship of self- } \\
& \text { control to unhealthy credit card } \\
& \text { usage of career women in } \\
& \text { Surabaya. }\end{aligned}$ & $\begin{array}{l}R=-0.266 \\
\rho=0.024\end{array}$ & $\mathrm{H} 2$ was rejected \\
\hline $\begin{array}{l}\text { H3: there is a relationship of } \\
\text { neuroticism personality } \\
\text { tendency to unhealthy credit } \\
\text { card use of career women in } \\
\text { Surabaya. }\end{array}$ & $\begin{array}{l}R=0.321 \\
\rho=0.006\end{array}$ & H3 was rejected \\
\hline
\end{tabular}

\section{Discussions}

The results of multiple correlation test for hypothesis 1 showed significant correlation between self-control and neuroticism personality tendency with unhealthy credit card usage of career women in Surabaya $(\mathrm{R}=0.447, \rho=$ $0.000)$. Therefore, it can be concluded that high and low self-control and neuroticism personality tendency can both have significant effects on unhealthy credit card usage.

The relationships of self-control and neuroticism personality tendency to unhealthy credit 
Devi Adilah Sandy \& Theda Renanita / The Relationships of Self Control and Neuroticism Personality Tendency to Unhealthy Credit Card Usage of Career Women in Surabaya / JEE, Vol. 7, No. 1, March 2018, pp 11-18

card usage is presumably due to the existence of self-control and neuroticism personality tendency altogether will strengthen someone's anxiety, driven by low self-control. For example, someone with low self-control and neuroticism personality tendency will be easily tempted by promotions for credit card user and feel regret if not purchasing the promoted product. If this credit card purchase continues to happen, it will put the credit card user at a risk of unhealthy credit card usage.

Next, the results of partial correlation test for hypothesis 2 showed no significant correlation between self-control with unhealthy credit card usage $(r=-0.266 \rho=0.024)$, so the second hypothesis was rejected. Therefore, it can be concluded that high and low self-control does not have significant effect on unhealthy credit card usage. Susanti and Nurwidawati (2014) explain that individuals with high selfcontrol can control themselves from behaviors that can do harm to them. Meanwhile, Aroma and Suminar (2012) explain that individuals with high self-control will be so aware of the consequences of their actions. Based on the research result, the researchers assume that individuals with high self-control will be very careful with their actions, especially in using their credit card to make purchase.

For the hypothesis 3, the partial correlation test result showed no significant correlation between neuroticism personality tendency with unhealthy credit card usage $(\mathrm{r}=0.321 \mathrm{p}$ $=0.006$ ), thus the hypothesis 3 was rejected. This result means that high and low neuroticism personality tendency does not provide significant effect on unhealthy credit card usage. Based on this result, the researchers assume that individuals with neuroticism personality tendency, when their emotions are unstable, will tend to put away their rationale consider- ation when making purchase, resulting in bad purchasing decision. Bad purchase decision can make individuals with neuroticism personality tendency feel threatened, become emotional instability, thus leading to regret after purchasing something. This assumption is supported by Zeelenberg and Pieters (2006) who claim that individuals with neuroticism personality will tend to easily regret their decisions made without consideration under emotional instability condition. This tendency to regret their purchasing decision will stop them from accumulating their credit card debts.

From this study, it is known that career women with range of age between $31-40$ years old got high scores for their unhealthy credit card usage. Hurlock (in Feist \& Feist, 2010) explains that someone in the 31-40 year age range is included in early adult development. Warner (in Feist \& Feist, 2010) furthermore explains that as humans begin to enter adult development stage, they will pass the stage of life achievement. The age of $31-40$ years old is the period where someone establishes his or her position as an adult person. In this period, individuals begin to take responsibility for managing their own life since they are no longer under their parents' care. This is the period where individuals are faced with various problems such as problems at work, with partners, in marriage, with children, or financial problems (Aldwin, 1991). These problems will eventually drive individuals to cope with stress they are under. Shopping is one popular way to cope with stress (Hama, 2001). Individuals with this period also already have a steady job so their credit card application is easily approved. However, individuals under continuous stress will also have to cope with stress continuously. Having a credit card allegedly will strengthen their stress-coping effort, resulting them to be 
Devi Adilah Sandy \& Theda Renanita / The Relationships of Self Control and Neuroticism Personality Tendency to Unhealthy Credit Card Usage of Career Women in Surabaya / JEE, Vol. 7, No. 1, March 2018, pp 11-18

at risk of unhealthy credit card usage. This statement is supported by Veludo-deOliveira (in Mendes-Da-Silva, 2012) who states that individuals in early adulthood stage develop a compulsive tendency when using credit card.

\section{Conclusions}

Based on the analysis and discussions, the following conclusions are derived:

1. Self-control $\left(X_{1}\right)$ and neuroticism personality tendencies $\left(\mathrm{X}_{2}\right)$, when tested simultaneously on unhealthy credit card usage $(\mathrm{Y})$ have significant relationships.

2. Self-control (X1) and unhealthy credit card usage $(\mathrm{Y})$ do not have significant relationship.

3. Neuroticism personality tendency $\left(X_{2}\right)$ and unhealthy credit card usage $(\mathrm{Y})$ do not have significant relationship.

Based on the research analysis, discussions, and conclusions, the limitations of this research are listed as follows:

1. This research only took 73 people as respondents due to the time limitation, which was only a month. It is suggested for future researcher to increase the sample size in order to make generalization.

2. There were no criteria being established on who paid the credit card bills, so there is a chance of bias.

3. Non-random sampling was used as sampling technique, so the subjects did not represent the intended population, thus this research results cannot be generalized.

4. The scales used to measure the data were adapted and translated scales, therefore there is a chance of bias.
The researchers then suggest as follows:

1. Future researchers can expand this research topic by doing analysis on other variables in relation to unhealthy credit card usage, such as lifestyle and compulsive behaviors.

2. Next research can limit the criteria of subjects' age, from early adulthood age of range to middle adulthood age of range.

3. Future researchers can conduct research on subjects with bigger size, in order to make the research results more valid.

4. This research contributes to the insight for career women, since from this research it is found that each self-control and neuroticism personality tendency have no relationships with unhealthy credit card usage.

5. This research contributes as a reference for banks or credit card issuers, since from this research it is found that each self-control and neuroticism personality tendency have no relationships with unhealthy credit card usage.

\section{References}

AKKI. 2016. Asosiasi Kartu Kredit Indonesia (Indonesian Credit Card Association). Accessed on http://www.akki.or.id/index. php/cr, 3 March 2016.

Aldwin, C. 1991. Does Age Affect the Stress and Coping Process? Implications of Age Differences in Perceived Control. Journal of Gerontology: Psychological Sciences, 46, 174-180.

Aroma, I.S. \& Suminar, D.R. 2012. Hubungan antara Tingkat Kontrol Diri dengan Kecenderungan Perilaku Kenakalan Remaja. Jurnal Psikologi Pendidikan dan Perkembangan, 1(2), 1-6. 
Devi Adilah Sandy \& Theda Renanita / The Relationships of Self Control and Neuroticism Personality Tendency to Unhealthy Credit Card Usage of Career Women in Surabaya / JEE, Vol. 7, No. 1, March 2018, pp 11-18

Chen, M.H. 2001. The Determinants and Traits of Impulsive Buying Behavior. Journal of Takming University, 17, 59-74.

Cohen, M.J. 2007. Consumer Credit, Household Financial Management, and Sustainable Consumption. International Journal of Consumer Studies, 31(1), 57-65.

Feist, Jess \& Feist, Gregory. 2010. Teori Kepribadian: Theories of Personality. Edisi Tujuh. Jakarta: Salemba Humanika.

Hama, Yasuhisa. 2001. Shopping as a coping behavior for stress. Japanese Psychological Research, 43(4), 218-224.

Huang, L.C. \& Lin, H.H. 2006. The Influence of Unawareness Set and Order Effects in Consumer Regret. Journal of Business and Psychology, 1-19.

John, O.P. \& Srivastava, S. 1999. The Big-Five Trait Taxonomy: History, Measurement, and Theoretical Perspectives. In L.A. Pervin \& O.P. John (Eds.), Handbook of personality: Theory and Research (Vol. 2, pp. 102-138). New York: Guilford Press.

Khalil, M.A.K.M., Mohamad, L., Mohamad, R.K., Alwi, N.H., Chun, L.S. 2015. Credit Card Practices, Attitudes, Problems and Risks among Individuals: Empirical Findings using Structural Equation Model. OUM International Journal of Business and Management, 1 (1), 12-23.

Kurniawan, F.Y., Suparna, G. 2014. Peran Kepemilikan Kartu Kredit dalam Memoderasi Pengaruh Kontrol Diri dan Atmosfer Gerai terhadap Perilaku Belanja Kompulsif Konsumen Pakaian di Kuta. E-Jurnal Manajemen Universitas Udayana, 3(6), 16851698.

Mendes-Da-Silva, W., Nakamura, W.T., \& de Moraes, D.C. 2012. Credit Card Risk
Behavior on College Campuses: Evidence from Brazil. Brazilian Administration Review, 9 (3), 351-373.

Mitchell, T.R., \& Mickel, A.E. 1999. The Meaning of Money: An Individual-Difference Perspective. Academy of Management Review, 24(3), 568-578.

Nyhus, E.K., \& Webley, P. 2001. The Role of Personality in Household Saving and Borrowing Behavior. European Journal of Personality, 15, 85-103.

Phau, I. \& Woo, C. 2008. Understanding Compulsive Buying Tendencies among Young Australians the Roles of Money Attitude and Credit Card Usage. Marketing Intelligence \& Planning, 26(5), 441-458.

Pirog, S.F. \& Roberts, J.A. 2007). Personality and Credit Card Misuse among College Students: The Mediating Role of Impulsiveness. Journal of Marketing Theory and Practice, 15(1), 65-77.

Ramdhani, N. 2007. Apakah Kepribadian Menentukan Pemilihan Media Komunikasi? Metaanalisis terhadap Hubungan Kepribadian Extraversion, Neuroticism, and Openness to Experience dengan Penggunaan email. Jurnal Psikologi, 34(2), 112-129.

Roberts, J.A. \& Jones. E. 2001. Money Attitudes, Credit Card Use, and Compulsive Buying among American College Students. The Journal of Consumer Affairs, 35(2), 213-240.

Safakli, O.V. 2007. Motivating Factors of Credit Card Usage and Ownership: Evidence from Northern Cyprus, Investment Management and Financial Innovations. 4(4), 123-136.

Sumarto, Subroto, A., \& Arianto, A. 2011. Penggunaan Kartu Kredit dan Perilaku 
Devi Adilah Sandy \& Theda Renanita / The Relationships of Self Control and Neuroticism Personality Tendency

to Unhealthy Credit Card Usage of Career Women in Surabaya / JEE, Vol. 7, No. 1, March 2018, pp 11-18

Belanja Kompulsif: Dampaknya pada Risiko Gagal Bayar. Jurnal Manajemen Pemasaran, 06(1), 1-7.

Susanti, E. \& Nurwidawati, D. 2014. Hubungan antara Kontrol Diri dan Konformitas dengan Prokastinasi Akademik pada Mahasiswa Program Studi Psikologi Unesa. Character, 2(3), 1-7.

Tangney, J.P., Baumeister, R.F., \& Boone, A.L. 2004. High Self-Control Predicts Good Adjustment, Less Pathology, Better Grades, and Interpersonal Success. Journal of Personality, 72(2), 272-322.

Talamati, B.P. 2012. Hubungan antara Trait Kepribadian Neuroticism dan Psychologi- cal Well-being pada Mahasiswa Tingkat Akbir Universitas Indonesia (Skripsi yang diterbitkan). Program Studi Sarjana Reguler Depok.

Yoyok, D.S. 2012. Pengaruh Personality Traits terhadap Penggunaan Kartu Kredit dengan Locus of Control sebagai Variabel Moderating (Studi terhadap Karyawan PT Kinocare Era Kosmetindo Jakarta) (Skripsi yang Diterbitkan). Salatiga: Program Studi Manajemen FEB Universitas Kristen Satya Wacana.

Zeelenberg, M. \& Pieters, R. 2006. A Theory of Regret Regulation 1.0. Journal of Consumer Psychology, 17(1), 3-1. 